\title{
Tick Fauna of Small Ruminants in South Part of Serbia, with Emphasis to North Kosovo
}

\author{
Ivan PAVLOVIĆ ${ }^{*}$, Valentina MILANOVIĆ ${ }^{2}$, Bisa RADOVIĆ ${ }^{2}$, Snežana IVANOVIĆ ${ }^{1}$, Milan P. PETROVIĆ ${ }^{3}$, \\ Violeta CARO-PETROVIĆ ${ }^{3}$ Jovan BOJKOVSKI ${ }^{4}$ \\ ${ }^{1}$ Scientific Veterinary Institute of Serbia, Belgrade, Serbia \\ ${ }^{2}$ Faculty of Agriculture, Lesak, University of Pristina, Kosovska Mitrovica, Serbia \\ ${ }^{3}$ Institute for animal Husbandru, Beograd-Zemun, Serbia \\ ${ }^{4}$ Faculty of Veterinary Medicine, University in Belgrade, Belgrade, Serbia \\ * corresponding author: dripavlovic58@gmail.com
}

Bulletin UASVM Veterinary Medicine 77(1)/2020

Print ISSN 1843-5270; Electronic ISSN 1843-5378

doi:10.15835/buasvmcn-vm: 2019.0034

\begin{abstract}
The study regarding tick fauna and season distribution of ticks of small ruminant in the south part of Serbia, with emphasis on north Kosovo was performed during 2017. During the study we examined a total of 114 flocks of goats and sheep from Zvečan and Leposavić districts (villages Ceranja, Majdevo, Zemanica, Mure, Rudine, Žitkovac, Oraovica, Mošnica, Donji Krnjin, Belo brdo, Mioliće, Drenova and Beliće). Infections occurred at and on 56.14\% of examined sheep and $31.42 \%$ of examined goats. The most abudant tick species were Ixodes ricinus, followed by Dermacentor marginatus, Rhipicephalus sanguineus, R.bursa, Haemaphysalis punctata and D.recticulatus.
\end{abstract}

Keywords: ticks, goats, sheep, south Serbia, north Kosovo

\section{Introduction}

Breeding of small ruminants in the hilly and mountainous areas of Serbia has a long tradition and is well developed. Nowadays small flocks of sheep and goats play an important role in providing animal protein for diet, especially for local people who live there. Sheep and goats are milked and they produce the bulk milk supply, together with a large proportion of the meat is being consumed (Ivanović and Pavlović, 2015).

They are usually kept under extensive conditions and graze or brows on any land that is not being cultivated (Pavlović et al., 2009). Usually these are small herds where goats and sheep are kept together. The way of breeding may have prerequisite to several infections including ticks infestation. In pasture breed conditions tick infestations are common especially during late spring and autumn months (Pavlović et al., 1995;
Milutinović etal.,1998). The aim of our examination was to establish the tick fauna parasitizing on flocks of goats and sheep in the south part of Serbia, with emphasis on north Kosovo (which status is in accordance with UNSCR 1244 and the Opinion of the International Court of Justice on the Kosovo Declaration of Independence).

\section{Materials and methods}

During 2017 we examined flocks of small ruminants from Zvečan and Leposavić districts, in villages Ceranja, Majdevo, Zemanica, Rudine, Žitkovac, Mure, Oraovica, Mošnica, Donji Krnjin, Belo brdo, Mioliće, Drenova and Beliće (Figure 1).

The geographical conditions in the examined area are favourable for breeding small ruminants because of the large number of pastures suitable for grazing. The relief is characterized by plateaus, hilly land, hills, mountains, numerous mountain 
ranges (saddles), valleys and rivers with a number of smaller tributaries. Flat land is rare. The continental climate is prevalent throughout the whole area with cold, relatively dry winters and warm, humid summers.

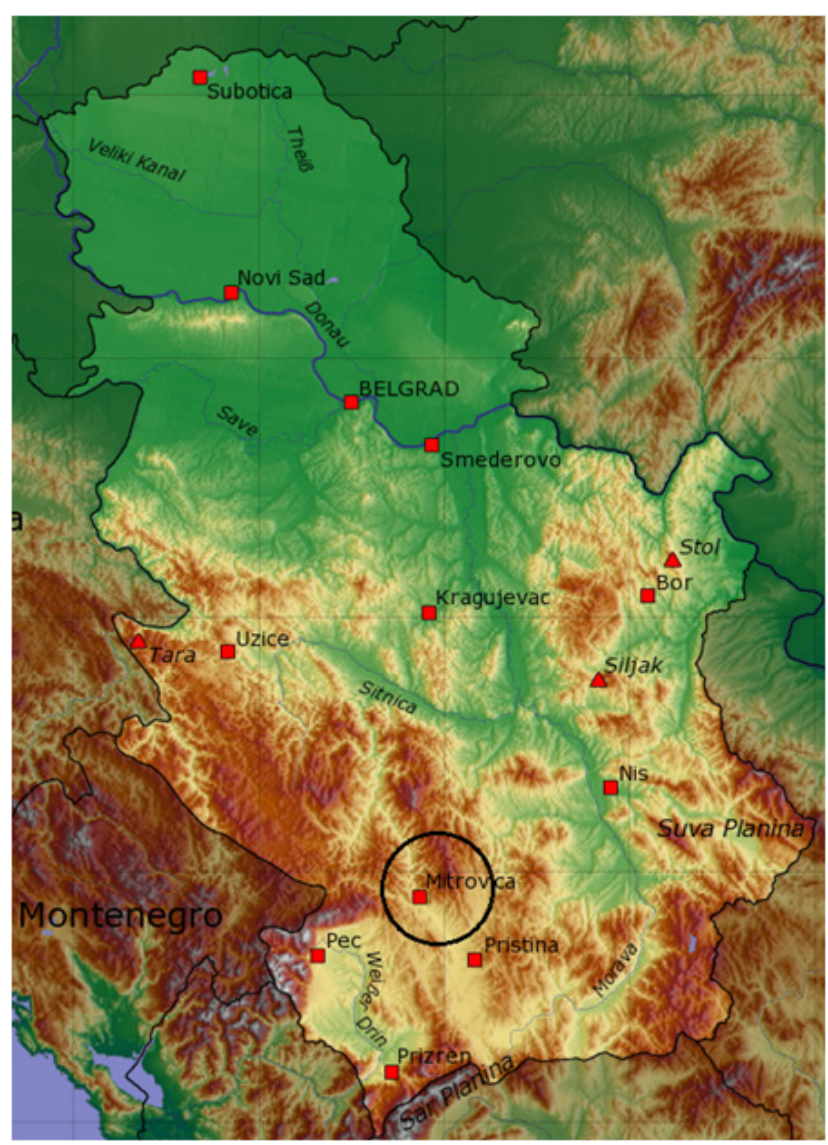

Figure 1. Map of Serbia with marked research area

In total, we examined 426 sheep and 172 goats from 114 flocks. The study about tick fauna and season distribution of tick was started in March and finished in October 2017. Ticks were collected monthly.

Ticks collected on pasture from sheep and goats by means lightly sprung forceps. All specimens were placed into glass specimen bottles which had a piece of hard paper inserted bearing the name of locality name of host and date and hour of collection. Colleagues who sampled ticks sent only adult ticks so we didn't get development forms for examination.

The tick species and sex were identified by morphometric characteristics. Each species has identifying features that are most distinguishable in the adult stage. They can be identified based on the festoons on the edge of the abdominal area, the appearance of the dorsal shield, and the shape of the mouth parts. Size can also be used in identification. For identification we use keys given by Pomerancev (1950) and Kapustin (1955).

\section{Results and discussions}

Ticks were found in all examined flocks. Ixodes ricinus were found on $42.45 \%$ of examined animals; same for the following by Dermacentor marginatus found in $17.41 \%$, Rhipicephalus bursa in $16.72 \%$, R.sanguineus in $6.22 \%$, Haemaphysalis punctata in $3.71 \%$ and D.recticulatus in $2.17 \%$. In total we collected 1774 ticks, 1274 from sheep and 500 from goats. The number of specimens of identified tick species per examined host is shown in Table 1.

On sheep tick infestation was detected in $56.14 \%$ of examined animals. The most abundant species was Ixodes ricinus found on 44.91\%, followed by Dermacentor marginatus (30.91\%), Rhipicephalus bursa (15.22\%), R.sanguineus (7.72\%), Haemaphysalis punctata (3.21\%) and D.recticulatus $(2.17 \%)$. The results are presented at Figure 2. During the examination, ticks were found on $31.42 \%$ of examined goats. The most abundant species was I. ricinus found on $42 \%$, followed by Rhipicephalus bursa (18.22\%), R. sanguineus (4.72\%), Haemaphysalis punctata (4.22\%) and Dermacentor marginatus (3.91\%). The results are presented in Figure 3.

Of the total number of collected ticks, $53.85 \%$ were females and $46.15 \%$ were males. A higher number of females were detected for Ixodes ricinus, Haemaphysalis punctata, Rhipicephalus sanguineus and Dermacentor marginatus. Higher number of males was detected for Rhipicephalus bursa and an equal number of ticks of the D.recticulatus. This is in agreement with the research of the tick sex ratio that have been made around the world (Milutinović, 1992; Milutinović et al., 1997; Anderson and Magnarelli, 2008).

In temperate habitats, feeding and generation cycles of hard ticks are closely synchronised with periods of suitable temperature and humidity conditions (Carrol and Kramer, 2003; Anderson and Magnarelli, 2008). The considerable interchange between spring and autumn tick populations can be attributed mainly to environmental conditions. In general, the climate in the exam- 
Table 1. The number of specimens of identified tick species per examined host

\begin{tabular}{lccc}
\hline \multirow{2}{*}{\multicolumn{1}{c}{ TICK SPECIES }} & \multicolumn{2}{c}{ HOSTS } & \multirow{2}{*}{ TOTAL } \\
\cline { 2 - 4 } & sheep & goats & \\
\hline Ixodes ricinus & 425 & 122 & 547 \\
\hline Dermacentor marginatus & 282 & 67 & 349 \\
\hline Rhipicephalus bursa & 174 & 124 & 298 \\
\hline Rhipicephalus sanguineus & 1000 & 74 & 174 \\
\hline Haemaphysalis punctata & 229 & 82 & 311 \\
\hline Dermacentor recticulatus & 64 & 31 & 95 \\
\hline TOTAL & 1274 & 300 & 1774 \\
\hline
\end{tabular}

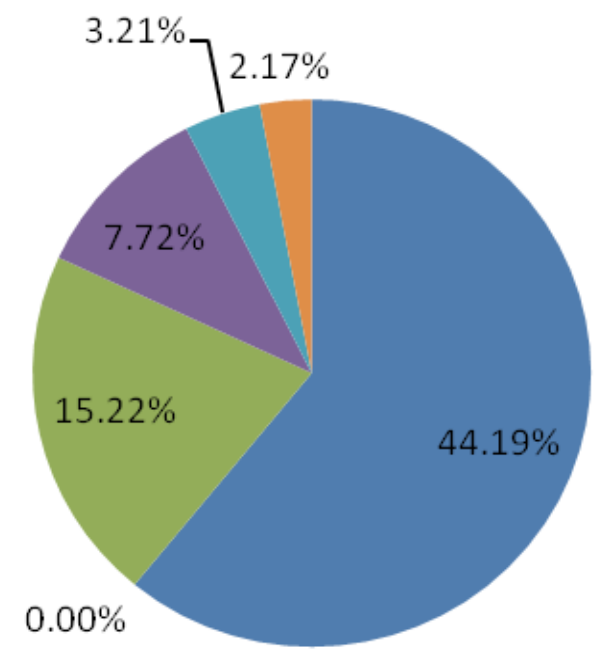

Ixodes ricinus

Dermacentor marginatus

Rhipicephalus bursa

Rhipicephalus sanguineus

Haemaphysalis punctata

Dermacentor recticulatus

Figure 2. Distribution of tick species in sheep

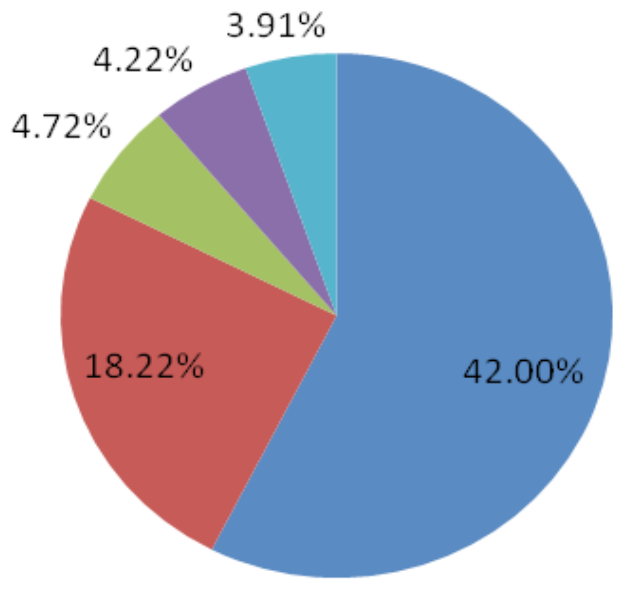

Ixodes ricinus

Rhipicephalus bursa

Rhipicephalus sanguineus

Haemaphysalis punctata

- Dermacentor marginatus

Figure 3. Distribution of tick species on goats 
ined area is continental, with cold, relatively dry winters and warm, humid summers. Summer temperatures in the mountainous areas are notably cooler, averaging about $18^{\circ} \mathrm{C}$ with up to 120 days of annual snow cover in the mountains. For these reasons, some species occur later than in the lowland and hilly parts of Serbia. The population dynamics of recorded tick species are known for their two maxima a year - in spring (April - May) and in autumn (September - October).

The population maximum for three species Dermacentor marginatus, D.recticulatus as well as Haemaphysalis punctata occured in April. May was the month of the population peak for I.ricinus and it was noted that this species started to decrease in abundance in June. R.hipicephalus sanguineus and R.bursa reached their maxima decreasing in August, and disappearing completely in September and October. The autumn population peak in September and in October occurred for I. ricinus, Dermacentor marginatus and Haemaphysalis punctata (Figure 4).

Similar results we obtained during examination of ticks fauna in western and eastern part of Serbia where I. ricinus and D. marginatus are the dominant tick species on sheep (Milutinović et al., 1996; Milutinović et al., 1998).

At the same time in the investigated areas at the goat $I$. ricinus and $H$. punctata were the most abundant species in contrast on Belgrade area and south Serbia where, except I. ricinus, the second dominant species was $R$. bursa (Milutinović et al., 1997; Dimitrić, 1999, Pavlović et al., 1999; Pavlović et al., 2002; Becskei et al., 2015).

The found species of ticks are the most common on sheep and goats in other coutries in the Balkans - North Macedonia, Montenegro and Bosnia and Hercegovina (Omeragić, 2011; Pavlović et al., 1995; Pavlović et al., 2014; Pavlović et al., 2016a, Pavlović et al., 2016c) and in Romania (Dumitrache et al., 2012, Mihalca et al., 2012).

\section{Conclusion}

During 2017 we examined 114 flocks of small ruminants from southern part of Serbia, at north Kosovo. Infection occurred at and on $56.14 \%$ of examined sheep and $31.42 \%$ of examined goats. Ticks represent one of the indispensable elements of that specific biotop.

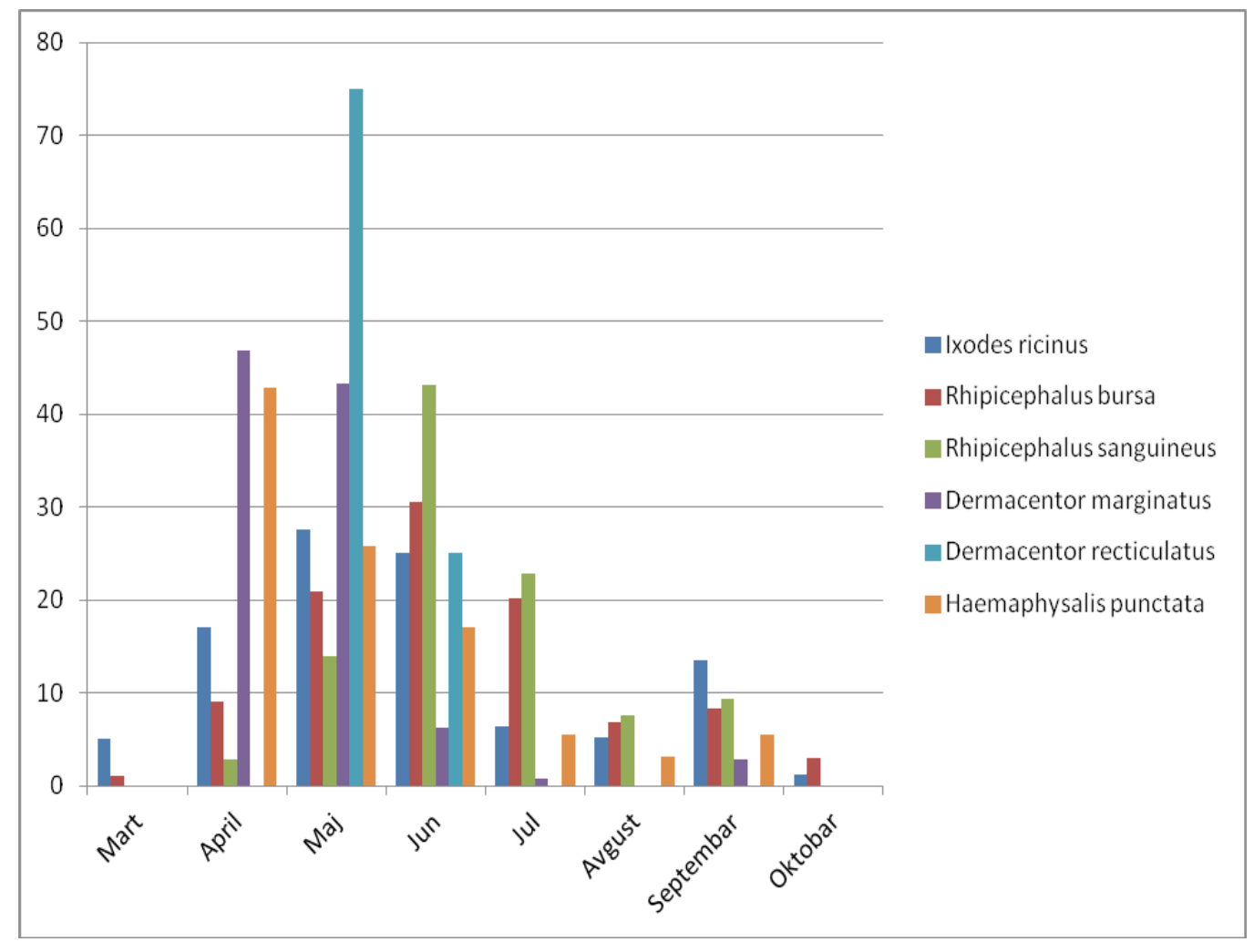

Figure 4. The population dynamics of collected tick species 
Acknowledgments. This research work was carried out with the support of Ministry of Education, Science and Technology Development and was financed from Project BT 31053.

\section{References}

1. Anderson JF, Magnarelli LA (2008). Biology of ticks. Infectious Disease Clinics of North America, 22(2):195215

2. Carrol JF, Kramer M (2003). Winter activity of Ixodes scapularis (Acari: Ixodidae) and the operation of deertargeted tick control devices in Mryland. Journal of Medical Entomology, 40:238-244.

3. Dimitrić A (1999). Fauna i ekologija krprelja (Acari:Ixodidae) kao prenosioca metazoonoza. MSc thesis, Faculty of Veterinary Medicine Belgrade

4. Dumitrache MO, Gherman CM, Cozma V, Mircean V, Györke A, Sándor AD, Mihalca AD (2012). Hard ticks (Ixodidae) in Romania: surveillance, host associations, and possible risks for tick-borne diseases. Parasitology Research, 110:2067-2070.

5. Ivanović S, Pavlović I (2015). Meso koza - bezbedna namirnica. Naučni institutza veterinarstvo Srbije. Beograd

6. Kapustin FU (1955). Atlas parazitov krovi životnih i klešćei iksodid. Gasudarstvenoe izdetejlstvo seljskohazjajstvenoi literaturi, Moskva

7. Mihalca AD, Dumitrache MO, Magdaş C, Gherman C, Domşa C, Mircean V, Ghira IV, Pocora V, Ionescu DT, Sikó Barabás S, Cozma V, Sándor AD (2012). Synopsis of the hard ticks (Acari: Ixodidae) of Romania with update on host associations and geographical distribution. Experimental and Applied Acarology, 58:183-206.

8. Milutinović M (1992). Ekološka istraživanja krpelja (Acarina,Ixodidea,Ixodia) Srbije, PhD disertation, Biology faculty University in Belgrade, Serbia.

9. Milutinović M, Petrović Z, Bobić B, Pavlović I (1996) Ecological notes on ticks colected in West serbia, Yugoslavia. Parasitologica Hungarica 29-30: p.67-74.

10. Milutinović M, Aleksić-Bakrač N, Pavlović I (1997). Ticks (Acari: Ixodidae,Argasidae) in the Belgrade area. Acta Entomologica Serbica, 2:77-85.

11. Milutinović M, Aleksić-Bakrač N, Pavlović I (1998a). Faunistic and ecological notes on ticks (Acari: Ixodidae,Argasidae) in the extended area of Belgrade. Magyar Allatorvosok Lapja 120:434-436.
12. Milutinović M, Aleksić-Bakrač N, Pavlović I (1998b). Reserch of tick population (Acari: Ixodidae) in eastern part of Serbia. Ars Veterinaria 14 (2):227-234.

13. Omeragic J (2011). Ixodid ticks in Bosnia and Herzegovina. Experimental and Applied Acarology, 53:301-309.

14. Pavlović I, Kulišić Z, Nešić D, Romanić S (1995). Ectoparasites of sheep and goats in Prizren district. Proceeding 3rd International Conference of Sheep and Goat Production, Ohrid, Macedonia, 101-105.

15. Pavlović I, Milutinović M, Kulišić Z, Dimitrić A, Pavlović V (1999). Prisustvo artropoda od biomedicinskog značaja na zelenim površinama grada Beograda. Zbornik radova II Gradske konferencije o suzbijanju štetnih artropoda i glodara sa međunarodnim značajem, Beograd,Serbia, 8187;

16. Pavlović I, Savić B, Ivetić V, Radanović O, Žutić M, JakićDimić D, Bojkovski J (2009). The effect of parasitic infections to production results of sheep. Proceeding IV Balkan Conference of Animal Science BALNIMALCON 2009, Challenges of the Balkan Animal industry and the Role of science and Cooperation,. Stara Zagora, Bulgaria, 389-391

17. Pavlović I, Jovčevski S, Jovčevski S, Kukovska V, Dimitrić A (2014). Tick fauna of sheep and cattle at Kumanovo arae (Macedonia). Lucrări Ştiinţifice Medicină Veterinară Timişoara, XLVII (3): 88-95.

18. Pavlović I, Ivanović S, Dimitrić A, Vegara M, Vasić A, Živković S, Mijatović B (2016a). Tick population in goats and sheep in Šabac. Macedonian Veterinary Review, 39 (1):103-109.

19. Pavlović I, Ivanović S, Savić B, Cvetojević Đ, Bojkovski J, Jovčevski Sr, Jovčevski St, Hadžić I, Rogožarski D, Dobrosavljević I (2016b). Krvni paraziti koza i ovaca. Zbornik naučnih radova Institut PKB Agroekonimk, 22 (34): 81-87.

20. Pavlović I, Jovčevski S, Rogožarski D, Csordás F, Mitrović N, Mijatovic I, Marčić D, Ćirković D, Šekler M, Ristić M (2016c). Biodiversity of ticks and fleas of dogs in the Western Balkans - results of preliminary examination. Bulletin of University of Agricultural Sciences and Veterinary Medicine Cluj-Napoca, 73 (2), 220-223.

21. Pomerancev BL (1950). Fauna SSSR. Paukobraznie. Iksodovie kleščei (Ixodidae). Izd. Akademem Nauk SSSR, Moskva-Leningrad 